\title{
The cultural sector's productive chain in Brazil: estimation and structural change from 2011 to 2015
}

A cadeia produtiva do setor cultural no Brasil: estimação e mudança estrutural de 2011 para 2015

\author{
Henrique Morrone (1) \\ Leandro Valiati (2) \\ (1) Universidade Federal do Rio Grande do Sul \\ (2) Universidade Federal do Rio Grande do Sul
}

\begin{abstract}
The objective of this article is to estimate the productive chain of the cultural sector in the Brazilian economy between the years 2011 and 2015 and to evaluate its structural change throughout this period. We estimated the input-output matrices for the years 2011 and 2015 using the methodology developed by Guilhoto and Sesso (2005). The method developed by Dietzenbacher et al. (2005) was applied in order to detect the productive chain and its evolution during this period. The results indicate that the cultural productive chain expanded during this period, incorporating new connections and contributing positively to the Brazilian economy. The cultural sector was classified as a net user of inputs from the rest of the economy. It showed strong direct and indirect backward linkages, purchasing intermediary inputs from many activities. Within the cultural sector, the artistic, creative and entertainment activities were highlighted.
\end{abstract}

\section{Keywords}

input-output analysis, productive chains, economic development.

JEL Codes O1, R15, Z10.

\section{Resumo}

O objetivo deste artigo é estimar a cadeia produtiva do setor cultural na economia brasileira nos anos 2011 e 2015, e avaliar sua mudança estrutural ao longo desse periodo. Estimamos as matrizes de insumo-produto para os anos 2011 e 2015 utilizando a metodologia desenvolvida por Guilhoto e Sesso (2005). O método desenvolvido por Dietzenbacher et al. (2005) foi aplicado com o intuito de detectar a cadeia produtiva e sua evolução no período supracitado. Os resultados indicam uma mudança na cadeia produtiva nesse periodo. A cadeia produtiva cultural expandiu, incorporando novas conexões e contribuiu positivamente para a economia brasileira. O setor cultural foi classificado como um usuário líquido de insumos do resto da economia. Ele mostrou fortes ligações diretas e indiretas para trás, comprando insumos intermediários de muitas atividades. No setor cultural, destacaram-se as atividades artísticas, criativas e de entretenimento.

\section{Palavras-chave}

análise insumo-produto, cadeias produtivas, desenvolvimento econômico.

Códigos JEL O1, R15, Z10. 


\section{Introduction}

One important question in economic theory concerns the impact of industry and "high-tech" services in the economy. There is a vast amount of literature discussing the benefits of these sectors and its linkages within the economy to the promotion of growth (Kaldor 1966; Reinert 2005; Dasgupta and Singh 2005). However, scant attention has been given to cultural activities and their interrelations with the rest of the economy. They can positively affect the economy throughout their productive links, demanding and supplying inputs from the rest of the economy.

In the input-output literature, there are three broad ways to estimate structural interrelations. Firstly, simpler methods can be used - based on the Leontief's (1986) contribution - by finding the key economic sectors for various periods, i.e., sectors that contain high backward and forward linkages. Sectoral interrelations and structural change would imply changes had occurred in key sectors over time. Chenery and Watanabe (1958) and Rasmussen (1956) are two seminal studies that apply simple methods to assess the interdependencies of a productive structure. Secondly, there are methodological extensions that allow for the study of structural change: triangulation (Korte and Oberhofer 1971), fields of influence (Hewingset al. 1989), structural decomposition (Messa 2013) and the eigenvector method (Dietzenbacher 1992). The results from these methods reflect the size and intensity of the sectoral productive linkages in the whole economy over time and point out changes in these linkages. Thirdly, qualitative inputoutput analysis (OIOA) can be applied with a focus on the existence of fundamental sectoral linkages in the economy. OIOA attempts to capture the basic economic structure or the "skeleton" of the economy (Gosh and Roy 1998). Using the Graph theory, researchers transformed the quantitative input-output matrix into a binary matrix (with zeros and ones only) that can be displayed on a directed graph. They normally use filters to select the intersectoral relationship that is relevant. This procedure can shed light on the basic changing structure of an economy.

In this paper, we estimated the cultural sector's productive chain in Brazil using a hybrid approach. We employed Dietzenbacher et al.'s (2005) technique that considers linkage size and distance between sectors to 
analyse the productive structure in terms of production chains ${ }^{1}$ - defined as the process that captures for a given sector the early stages in production up to the final demand stage (Dietzenbacher et al. 2005). We applied the methodology proposed by Guilhoto and Sesso (2005) to construct I-O matrices for 2011 and 2015 from the National Statistical Accounts. Using these matrices, we computed the productive chains for 2011 and 2015. The gauged matrices for 2011 and 2015 served as a benchmark for analysing the structure during this period.

The 2011-2015 period represents a phase of profound changes in the Brazilian economy. The previous developmental model, based on distributive policies and booming commodities prices, started to reveal its limits by 2014, and Brazil began to experience a deep political and economic crisis in 2015. However, the cultural activities expanded somewhat in the country. While the number of total jobs in the economy declined, employment in cultural activities slightly increased between 2014 and 2015 (Sanguinet et al. 2016). Average wages in this sector increased moderately until 2013 but then fell due to the economic crisis. For example, the audiovisual sector (an important and substantial part of the cultural sector), grew from 2007 to 2014 . The audiovisual value added rose from 21.9 billion Reals in 2010 to 29.5 billion in 2014, thus increasing its participation in the whole economy (Morrone 2017). ${ }^{2}$

This study can throw some light on the qualitative changes in the cultural sector and its interplay with the rest of the economy. To our knowledge, an empirical and meso-economic study of the cultural sector's productive chain in Brazil is lacking. With this in view, the current paper attempts to fill this gap in the literature.

This article contains three additional sections. In the following section, we present a brief review of the cultural sector in Brazil. The method and data are presented in Section 3. The remaining two sections exhibit results and conclusions.

1 The analysis of production chains is important in fields such as vertical integration, outsourcing and supply-chain management (Dietzenbacher et al. 2005).

2 We cited the audiovisual sector because it presents more data available when compared with the rest of the cultural activities. 


\section{Culture, economy and development in Brazil: the UK paradigm in an unstable experience}

Cultural industries play a key role in promoting economic development (UNCTAD 2004, 2008, 2010). ${ }^{3}$ These industries require intensive knowledge and a high level of workforce qualification, human creativity and innovation. These features are drivers of quality employment, especially in industries with a high concentration of creative inputs. Moreover, the creative economy also improves economic diversification, trade, innovation, regional development and internal and external investment (UNCTAD 2004, 2010; Sanguinet et al. 2016; Cunha et al. 2016).

Another relevant aspect concerns their role in promoting social inclusion, facilitating the spread of cultural activities in communities and the inclusion of marginalized workers, usually located in the informal sector (Valiati and Cauzzi 2016). In addition, the creative economy has a broad cultural impact when considering its cultural and economic values. Thus, many countries perceive in these industries a sustainable alternative for fostering economic development (UNCTAD 2008, 2010).

During the crisis of the mid-70s, developed economies, e.g., Australia and the UK, adopted a developmental strategy focused on dynamic sectors, characterized by creativity, innovation and symbolic value production (Throsby 2003). In this context, the United Kingdom assumed a key role in designing strategic policies to promote creative industries. The emphasis was on activities that, based on inputs of cultural value, promoted technological innovation, urban reconfiguration and intellectual property. The institutional genesis of this policy is linked to the elected New Labour government of 1997 which established the Creative Industries Task Force (CITF) as a core activity of its new Department of Culture, Media and Sports (DCMS). ${ }^{4}$ The CITF became responsible for mapping the creative sectors

3 Furtado (1984) was one of the Latin American pioneers in the study of the relationship between culture in general and the development and underdevelopment processes. He tried to redefine economic development theory, bringing culture into the analysis (Cunha and Britto 2018).

4 DCMS considers in its action sectors of the economy that have a greater proportion of creative workers among its total number of employees (Bakhshi, Freeman and Higgs 2013; DCMS 2016). Creative workers, in turn, are defined according to a listing of 30 occupancy codes which are divided into nine subgroups: advertising and marketing; architecture; crafts; design; film, television, video, radio and photography; information technology (IT), computer software and services; editorial; museums, galleries and libraries; and music, performing 
in order to measure and monitor their economic dimensions. Thus, there is a structured project to explore commercial potential, strategic economic importance and international branding of UK-related goods with symbolic cultural value. In addition to traditional artistic expressions, this project considers activities related to copyright, innovation and knowledge (Bakhshi, Freeman and Higgs 2013). ${ }^{5}$ The results of this public policy are robust. According to DCMS (2016) ${ }^{6}$, the creative industries' gross value added (GVA) increased 6.0 per cent each year between 1997 and 2014. The GVA of the creative industries was 3.9 per cent of the UK GVA in 1997 and increased to 5.2 per cent in 2014 . The export of services from the creative industries accounted for 8.7 per cent of total exports of services in 2013. These industries accounted for 1 in 17 (5.8 per cent) of all jobs in the UK in 2015.

In recent years, Brazil has debated the importance of the creative economy and cultural industries as a developmental strategy. In the last decade, a policy aimed at fostering activities in creative and cultural segments and their interplay emerged. In 2010, for example, the National Secretariat of creative economy was created in the Ministry of Culture and a national plan for a creative economy was developed. The plan was influenced by the British model, focusing on new business models, entrepreneurship and popular grassroots culture. This National Secretariat was abolished in 2014 (within the re-elected government of President Dilma Roussef), thus losing institutional strength, and was replaced by policies associated with the economy of culture. With the presidential impeachment in 2016, however, the theme has maintained prominence in the government.

In this scenario, a technical approach to supporting policies aimed at the development of the creative industries is necessary. Appropriate institutional mechanisms and a greater coordination between the agents that have competencies in this area is also required. As UNCTAD (2008) argues, critical areas requiring new policy initiatives in developing countries include the provision of financing, infrastructure, an adequate regulatory framework, promotion of exports, establishment of clusters and effective data collection and analysis.

arts and visual arts. Note that in addition to occupations linked to artistic and cultural activities, they are also considered occupations related to software development, management, marketing and information technology.

5 Bakhshi, Freeman and Higgs. A dynamic mapping of the UK's creative industries. London: Nesta, 2013.

6 DCMS, Official Statistics, Key Findings, 2016. 
The Brazilian policy for the cultural sector was different from the English model. Considering the four models that capture the relationship between the creative industries and the rest of the economy in Potts and Cunningham $(2008)^{7}$, it is possible to make a brief historical record. In the first Lula Government (2002), there was a political and strategic affirmation of great value to UNCTAD led by Minister Gilberto Gil. The national plan of culture was created in the second Lula Government (2006), associating the cultural economy with development. A welfare vision of creative industries arose in which diversity, social impacts and inclusion were central. In the first Dilma Roussef government (2010-2014), there was the construction of a long-term plan (Creative Brazil Plan) that was somewhat influenced by the British model. The plan assumed that creative industries produce positive externalities that foster economic development. Moreover, in 2012 the government implemented the Vale Cultura program through which firms could receive tax breaks if they increased cultural benefits to workers. According to Henkin et al. (2016), the federal resources spent on culture slightly increased from 2010 to 2015, with the peak in 2012 (3.26 billion Reals). In the brief second term of Dilma Roussef, the welfare model returned; it was not consolidated due to the brevity of the government which was replaced by another political project.

Cunha et al. (2016) indicates that $6.9 \%$ of the Brazilian workforce is located in cultural and creative activities. The income of the cultural sector is smaller than the economy-wide average. In the case of using the social security contribution as a proxy for social protection, both sectors have lower formalization rates than the rest of the economy. In addition, cultural and creative sectors have a high level of informality, with formalization rates of $40 \%$ for the former and $50 \%$ for the latter. The formalization rate for the economy is $72 \%$ (Sanguinet et al. 2016). In terms of gender composition, males form the majority in creative activities, and genders are relatively equal in the cultural sector $(49.6 \%$ male and $50.4 \%$ female).

7 Potts and Cunningham (2008) proposed four models to investigate the dynamic relationship between creative industries and the whole economy: welfare (1), competition (2), growth (3) and innovation (4). In model (1), creative industries have a negative effect in the economy. Model (2) establishes that the creative industries are not a drag on the economy. They function as any other sector does in the economy. The growth model (3) argues for a positive economic relationship between creative industries and the rest of the economy. Creative industries drive economic growth in this model. Finally, the innovation model (4) indicates that creative industries are a key element in the innovation system of economies. 
In this context, the country has experienced unstable and random initiatives in stimulating cultural and creative industries. These activities are important in contemporary capitalism and can create opportunities for economic development. But in order to deal with this innovative paradigm, a strong public policy is needed based on recognition of the real impacts of cultural industries.

\section{Methodology and data}

To analyse the cultural sector's structure in a region, we present an inputoutput procedure to gauge the productive chain. Leontief (1986), Rasmussen (1956) and Hirschman (1958) are some of the pioneers in the study of structural change and development. The proxy of the cultural sector is formed by four activities: printing and reproduction of recordings; printintegrated editing and editing; television, radio, cinema and sound, image recording, editing activities; and artistic, creative and entertainment activities. Dietzenbacher et al.'s (2005) model is the template for our estimation of the productive chain. Here, both linkage size and distance between sectors play crucial roles. We then present the data.

\subsection{Method}

The procedure developed by Dietzenbacher et al. (2005) to estimate productive chains has four steps. Firstly, it is necessary to compute the "supply and demand" driven input-output matrices (IOM). In this stage, the size of the sectoral linkages is computed. Secondly, the average propagation length is calculated for both matrices. It shows how a cost push and a demand pull proliferate within the economy. Thirdly, we averaged the size for a cost push and a demand pull. This calculates the mean of the backward and forward impacts of every sector in the economy. Fourthly, we applied a filter to show the basic economic structure. This technique allows us to compute the productive chains for a given activity, which are depicted in Figure 1. 
Figure $1 \mathrm{~A}$ productive chain for a hypothetical activity

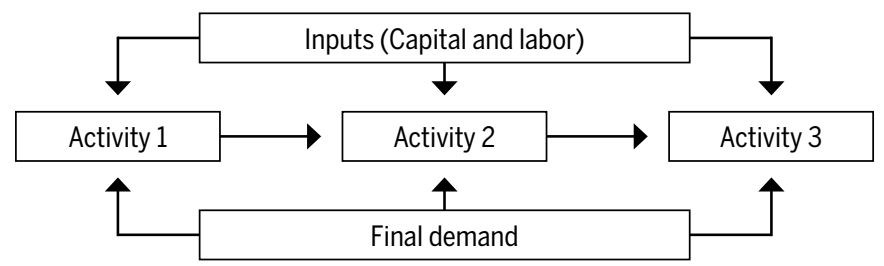

Source: Authors' elaboration based on Dietzenbacher et al. (2005).

Now that we have sketched the procedure, let us delve into the specifics. Herein we draw heavily on the notation and model presentation from Dietzenbacher et al. (2005). Table 1 exhibits the basic productive structure presented in a hypothetical economy.

Table 1 A schematic input-output table

\begin{tabular}{lcccccc|rrr}
\hline & & & & & & Sectors & $\begin{array}{r}\text { Final } \\
\text { demand }\end{array}$ & $\begin{array}{r}\text { Total } \\
\text { demand }\end{array}$ \\
\hline Sectors & & $\mathrm{x}_{11}$ & $\mathrm{x}_{12}$ & $\mathrm{x}_{13}$ & $\mathrm{x}_{14}$ & $\ldots$ & $\mathrm{x}_{1 \mathrm{n}}$ & $\mathrm{f}_{1}$ & $\mathrm{x}_{1}$ \\
\cline { 2 - 11 } & $\mathrm{x}_{21}$ & $\mathrm{x}_{22}$ & $\mathrm{x}_{23}$ & $\mathrm{x}_{24}$ & $\ldots$ & $\mathrm{x}_{2 \mathrm{n}}$ & $\mathrm{f}_{2}$ & $\mathrm{x}_{2}$ \\
\cline { 2 - 11 } & $\mathrm{x}_{31}$ & $\mathrm{x}_{32}$ & $\mathrm{x}_{33}$ & $\mathrm{x}_{34}$ & $\ldots$ & $\mathrm{x}_{3 \mathrm{n}}$ & $\mathrm{f}_{3}$ & $\mathrm{x}_{3}$ \\
\cline { 2 - 11 } & $\mathrm{x}_{41}$ & $\mathrm{x}_{42}$ & $\mathrm{x}_{43}$ & $\mathrm{x}_{44}$ & $\ldots$ & $\mathrm{x}_{4 n}$ & $\mathrm{f}_{4}$ & $\mathrm{x}_{4}$ \\
\cline { 2 - 11 } & $\mathrm{xn}_{1}$ & $\mathrm{xn}_{2}$ & $\mathrm{xn}_{3}$ & $\mathrm{xn}_{4}$ & $\ldots$ & $\mathrm{x}_{\mathrm{nn}}$ & $\mathrm{f}_{\mathrm{n}}$ & $\mathrm{x}_{\mathrm{n}}$ \\
\hline Primary inputs & $\mathrm{v}_{1}$ & $\mathrm{v}_{2}$ & $\mathrm{v}_{3}$ & $\mathrm{v}_{4}$ & $\ldots$ & $\mathrm{v}_{\mathrm{n}}$ & & \\
\hline Total supply & $\mathrm{x}_{1}$ & $\mathrm{x}_{2}$ & $\mathrm{x}_{3}$ & $\mathrm{x}_{4}$ & $\ldots$ & $\mathrm{x}_{\mathrm{n}}$ & $\mathrm{f}$ & \\
\hline
\end{tabular}

Source: Authors' elaboration.

The input-output matrix in Table 1 exhibits the productive structure of a given economy. In this table, $x_{i j}$ stands for the intermediary demand between sectors $i$ and $j ; f_{j}$ represents the final demand of product $j ; x_{j}$ gives the gross output of sector $j$; and $v_{j}$ denotes the total use of primary inputs in activity $j$.

This table illustrates the demand pull and supply-driven input-output models. If we employ the summation column vector e and its transposed $e^{\prime}$; that is, with $e^{\prime}=(1, \ldots, 1)$, it is possible to rewrite the input-output table using two accounting identities as follows: 


$$
\begin{aligned}
& x=X e+f \\
& x^{\prime}=e^{\prime} X+v^{\prime}
\end{aligned}
$$

Equation (1) expresses the demand-pull input-output model. The supply input-output model, also known as the Gosh model, is represented by equation (2).

Using the technical coefficient matrix A, formed by every $a_{i j}\left(a_{i j}=x_{i j} / x_{j}\right)$, equation (1) can be rewritten as

$$
x=A X+f
$$

which corresponds to the Leontief model. It captures backward linkages throughout the economy. For further details, see Miller and Blair (1985).

Under the usual assumptions of Leontief's model ${ }^{8}$, changes in final demand have an impact on sectors' production. The total effect can be decomposed in several rounds with direct and indirect repercussions for the economy. Equation (4) depicts this total effect on the economy:

$$
\Delta x=(I-A)^{-1}(\Delta f)=L(\Delta f)
$$

where $\Delta x$ stand for the change in gross output, $(I-A)^{-1}$ is the Leontief inverse and $\Delta f$ represents the initial change in the final demand. The Leontief inverse can be rewritten as a power series as follows:

$$
L=I+A+A^{2}+A^{3}+A^{4}+\ldots
$$

Using equation (5), it is possible to reveal the propagation of an initial shock in the final demand in the rest of the economy. An initial change in the final demand gives rise to multiple rounds. In round $0, \Delta f$ should be produced (or supplied) by the economy. To produce it, extra input needs to enter the market in order to satisfy the initial output in round 0 . This direct effect is equal to $A(\Delta f)$. To produce these extra products, further indirect increases in the production of inputs are necessary. In round $2, A^{2}(\Delta f)$ intermediate inputs are required.

8 The assumptions of the Leontief model are fixed prices and a constant technological coefficient matrix. 
In the same fashion, to supply these inputs, further production is repeatedly necessary. In a nutshell, the total change in output can be decomposed by an initial effect $(\Delta f)$, a direct one $(A(\Delta f))$ and its indirect rounds $\left(A^{2}+A^{3}+A^{4}+\ldots\right) \Delta f$. In this way, $l_{i j}$ indicates the rise in gross output in sector $i$ from an initial increase in final demand. It shows the origin of the inputs required to meet the rise in demand.

Analogously, we can find the forward linkages and examine the dependence of sector $i$ on the purchase of activity $j$. Employing the matrix $\mathrm{B}$ - comprised of the output coefficients $\left(b_{i j}=x_{i j} / x_{i}\right)$ - the accounting relationship (2) is expressed as:

$$
x^{\prime}=X B+v^{\prime}
$$

As explained earlier, this is the supply-driven input-output model. Assuming fixed output coefficients (B), the model shows the changes in output that result from changes in primary input $\left(\Delta v^{\prime}\right)$. Equation 7 exhibits this relationship as

$$
\Delta x^{\prime}=\Delta v^{\prime}(I-B)^{-1}=\Delta v^{\prime} G
$$

where the term $G \equiv(I-B)^{-1}$ is the Gosh inverse. It gives the direct and indirect effects of changes in primary costs in output values. In this sense, the model assumes fixed quantities.

A cost push can also be decomposed in many rounds in this case. The initial, direct and indirect effects are respectively $\left(\Delta v^{\prime}\right),\left(\Delta v^{\prime}\right) B$ and $\left(\Delta v^{\prime}\right)\left(B^{2}+B^{3}+B^{4}+\ldots\right)$. The element $g_{i j}$ of matrix $G$ indicates the rise in output values of sector $j$ that stems from a single monetary unit increase in primary inputs from sector $i$.

Having estimated the backward and forward linkages, the next step consists of finding the average propagation length. An initial demand pull propagates throughout the economy and results in a final impact (Dietzenbacher et al. 2005). A single monetary unit increase in sector $j$ 's final demand drives output in activity $i$ by $l_{i j}-\delta_{i j}$, disregarding the initial effect. $\delta_{i j}$ stands for the Kronecker delta; it is equal to one if $i=j$ and zero otherwise. A constant share $a_{i j} /\left(l_{i j}-\delta_{i j}\right)$ of the rise in output requires one round. The share $\left(A^{2}\right)_{i j} /\left(l_{i j}-\delta_{i j}\right)$ takes two rounds to propagate, that is, it requires two rounds to get from $i$ to $j$. Before sector $i$ gets to $j$, it reaches an 
intermediary sector. Further rounds can be modelled in a similar fashion. Adding every share gives the total effect with $n$ rounds. The round's sum is positive and equal to one. In this way, the average propagation length indicates the average number of rounds for a demand pull in sector $j$ to reach activity $i$. It can be written as:

$$
\left\{a_{i j}+2\left[A^{2}\right]_{i j}+3\left[A^{3}\right]_{i j}+4\left[A^{4}\right]_{i j}+\ldots\right\} /\left(l_{i j}-\delta_{i j}\right)
$$

In the case of a cost push, a similar procedure can be adopted. The average propagation of a cost push is

$$
v_{i j}=\left\{b_{i j}+2\left[B^{2}\right]_{i j}+3\left[B^{3}\right]_{i j}+4\left[B^{4}\right]_{i j}+\ldots\right\} /\left(g_{i j}-\delta_{i j}\right)
$$

If the numerator on the right-hand side of equation (9) is denoted by $H=\sum_{k} k B^{k}$, the terms $h_{i j}$ are computed as ${ }^{9}$

$$
H \equiv \sum_{k=1}^{\infty} k B^{K}=G(G-I)
$$

The matrix of average propagation is then equal to $h_{i j} /\left(g_{i j}-\delta_{i j}\right)$ if $g_{i j}-\delta_{i j}>0$ and zero otherwise.

From the analysis of equations (8) and (9), we can see that the average propagation length of a cost push is equal to a demand-pull injection. It is reasonable to assume that the average number of backward steps required to go from $j$ to $i$ is equal to the number of steps to pass over from $i$ to $j$. For additional details, see Dietzenbacher et al. (2005).

Now that the average propagation length matrix is available, the strength of the linkages can be computed. To do that, we built an F matrix according to the following equation.

$$
F=(1 / 2)[(L-I)+(G-I)]
$$

The $f_{i j}$ provides the size of the linkage. It is equal to the average of the backward and forward effects.

Finally, a filter was applied in matrix F to verify whether the linkage was large enough to be considered as relevant. From the qualitative input9 The equality can be proven since $G \equiv(I-B)^{-1}$, hence $(I-B) H=B+B^{2}+\ldots=G-I$. Thus, $H=(I-B)^{-1}(G-I)=G(G-I)$. 
output literature, the filter was set to be equal to $1 / \mathrm{m}$; that is, it is the inverse of the number of sectors in the economy (Souza 1989). The average propagation length was taken only if the size of the linkages was larger than the filter value; otherwise, they are set to be equal to zero.

Therefore, the presented method seems suitable for estimating and analysing the evolution of the cultural sector's productive chains in Brazil. It can emphasize the role played by this activity in the economy.

\subsection{Data}

The input-output matrices were computed from the National Statistical Accounts. We used the methodology developed by Guilhoto and Sesso (2005) to compute the MIP. The Use and Make tables for Brazil are employed as data sources for our estimations. After computing these matrices, we calculated the input-output matrices for 2011 and 2015. The matrices comprised 68 sectors. Table A1, in the Appendix A, shows the 68 sectors. The sectoral aggregation follows the Brazilian Statistical Office classification. Estimations were computed using UCINET VI software.

\section{Results for the cultural sector and its main compo- nents}

Figure 2 displays the results for the first distance linkages of the cultural sector in Brazil for the years 2011 and 2015. It shows the direct links of this sector with the rest of the economy. As mentioned before, the cultural sector consists of the following activities: printing and reproduction of recordings (18); print-integrated editing and editing (49); television, radio, cinema and sound, image recording, editing activities (50); and artistic, creative and entertainment (66). Even though it does not include all cultural activities, arguably these activities combined work as a proxy for the cultural sector.

A glance at Figure 2 shows some meso-economic features of the cultural sector. The sectors that sell to the cultural activity are located on the left side of this figure while sectors that purchase from it are on the right. Two 
results here are important. Firstly, the cultural sector's purchases surpass its sales to other sectors for year 2011. That is, it turns out that the cultural sector's backward dependency is spread throughout a higher number of setors when compared to its forward dependency. Overall, the cultural sector had 16 linkages in 2011. The in-degree (number of arrows toward the cultural sector) is nine, while the out-degree is seven. In other words, the sector is considered a user (Gosh and Roy 1998).

A user denotes a sector that absorbs products of the economy; they purchase more inputs from other sectors than they sell. In other words, the in-degree (incoming arrows in the vertex) is larger than the out-degree (emanating edges from the vertex or node). Conversely, source sectors are defined as having in-degrees smaller than out-degrees. A central activity is one that presents equal numbers of in-degrees and out-degrees.

Secondly, we detected an increase in the in-degree and a drop in the out-degree when comparing 2011 to 2015 . There were the same number of links in these productive chains but their composition in terms of indegrees and out-degrees changed. For 2015, nine sectors sold products to the cultural activity. This sector started to purchase products from real estate rentals and intellectual property asset management (58) and stopped selling products for the sector of development of systems and other information services (52). As a result, the cultural sector presented a modest rise in its in-degree and a fall in its direct sale to the rest of the economy in this period. In this sense, the cultural activity might be located more towards the end of the productive chain.

Figure 2 The cultural productive chain for Brazil in the year 2011 (a) and 2015 (b)

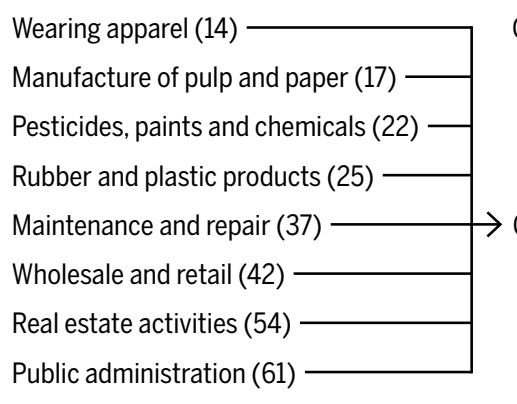

Other professional and scientific activities (57)

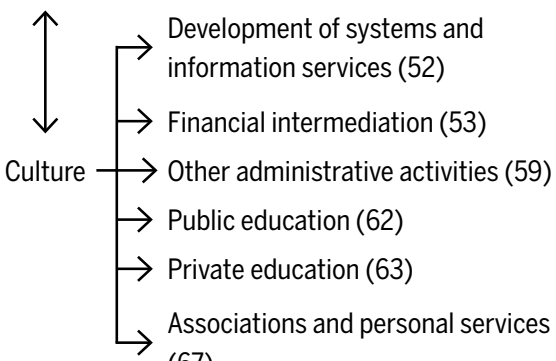

(67)

(a) 


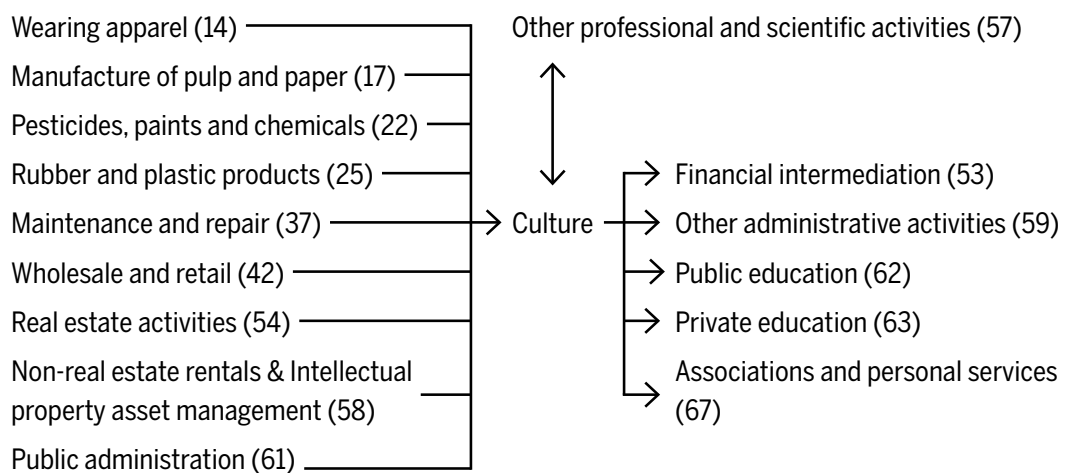

(b)

Source: Authors' elaboration.

Figure 3 plots the results for the second distance. It shows the indirect propagation of the cultural sector throughout the economy. Here the cultural sector demands from or sells indirectly to other sectors; i.e., the cultural sector purchases or sells through an intermediary sector. In this case, the cultural sector has a two-step dependency (backward or forward).

Although the graph is a bit cluttered (a cost of the high disagregation of the matrix), some results can be underscored. In 2011, the cultural sector exhibited 102 linkages: there were 65 sectors that the cultural sector indirectly purchased from (in-degree) and 37 sectors that it sold to in 2015. The number of sectors where the cultural sector has a two-step backward dependency is larger than the number for forward dependency.

Comparing these results with the year 2015 allows us to examine the changes in the productive interdependencies. The degree increased only slightly throughout the period. There was a fall in the in-degree (from 65 to 62) and an increase in the out-degree (from 37 to 41). It appears that the cultural sectors' two-step forward dependency involved a larger number of sectors; the opposite happened with the two-step backward dependency.

Turning the focus to the first distance results for the cultural sector components, further intersectoral relationships can be explored. (The results for the second distance are in the appendix). The results for 2011, reported in Figure 4, show that the four sectors that comprise cultural activity present different classifications. The sizes of the nodes indicate different sectoral degrees. The greater the size of a given node, the higher the number of its intersectoral linkages. The shape and colour of nodes were given 
automatically by the software UCINET VI. The numbers in the graph indicate the sectoral classifications presented in Table 2 in the appendix. Sector 18 (printing and reproduction of recordings) exhibits nine links, four of which are in-degrees and five out-degrees. It is a source sector since it sells more products than it purchases from the rest of the economy. The printintegrated editing and editing activity (49) is a source; it has eight linkages (five out-degrees and three in-degrees). Sector 50 (television, radio, movies and sound) has minor importance in the network; it has only two direct strong links classified as central (one in-degree and one out-degree). Finally, sector 66 (artistic, creative and entertaining activities) has eight connections (six in-degrees and two out-degrees), and this sector is a user. Overall, this is the unique net user in this network. Although not included as cultural activities, sector 57 (other professional, scientific and technical activities) is highly interconnected with the segments of the cultural sector. It shows an important link between cultural and creative activities.

Comparing the results from 2011 with 2015, we detect that the total number of direct linkages slightly increased. This higher number of interconnections suggests a rise in the role of cultural sectors in the economy. The density of the graph - a measure of the number of arcs in the network as a proportion of the maximum possible number of arcs (Nooy et al. 2011) - has improved. ${ }^{10}$ It is an important condition for economic development (Syrquin 1988). The rise in productive integration leads to a more complex network (ArocheReyes 2006). A higher integration also implies that public policies will diffuse their effects more easily within the network (Tarancón et al. 2008).

Figure 3 The second distance linkages of the cultural sector in 2011 (a) and 2015 (b) in

\section{Brazil}

(a)

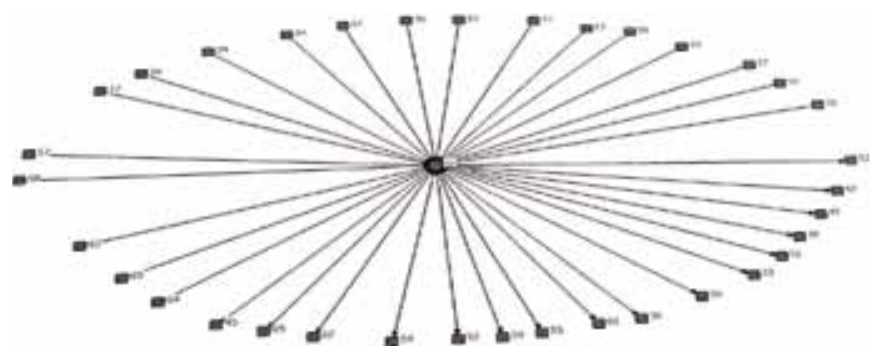

10 For the whole Brazilian economy, the density reduced from 4.80 to 4.53 per cent between 2005 and 2014, while between 2000 and 2010 it somewhat improved (Morrone 2018). In a crisis period, usually the density drops. 
(b)

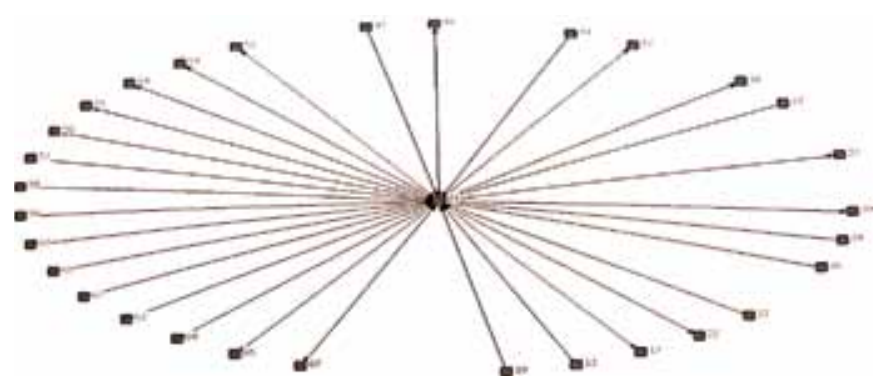

Source: Authors' own elaboration using UCINET VI software.

Three results are important. Firstly, sector 49 (print-integrated editing and editing) modestly increased its role as a source while sector 18 (printing and reproduction of recordings) dropped somewhat. The sector 49 (printintegrated editing and editing activities) increased its role as a source from 0.6 to 0.75 . Specifically, for sector 18 (printing and reproduction of recordings), a new connection with sector 52 (development of systems and other information services) disappeared in 2015.

Secondly, sector 50 (television, radio, cinema and sound/image recording/editing activities) that was classified as central in 2011 changed its role to that of a user. The in-degree/out-degree ratio is equal to 2 in 2015. A new link with sector 14 (manufacturing of wearing apparel and accessories) emerged.

Lastly, sector 66 (artistic, creative and entertainment activities) shows an improvement in position in 2015. The number of total linkages increased from eight to nine. A new connection with sector 58 (non-real estate rentals and intellectual property asset management) took place in 2015. Moreover, the in-degree/out-degree ratio rose from 3 in 2011 to 4.5 in 2015. In other words, this sector's role as a user intensified in this period.

The estimated results therefore show an evolution in the cultural production chain in Brazil. The network has expanded modestly. This improved "core" structure suggests the positive contribution of this sector to increasing the level of economic activity. In a scenario still marked by a profound economic and political crisis, the results highlight that cultural activities may positively affect the economy, contributing to the reignition of economic growth. The government's strategy should focus on these activities to help overcome the recession. 
Figure 4 The first distance linkages of the components of the cultural sector in 2011 (a) and 2015 (b) in Brazil

(a)

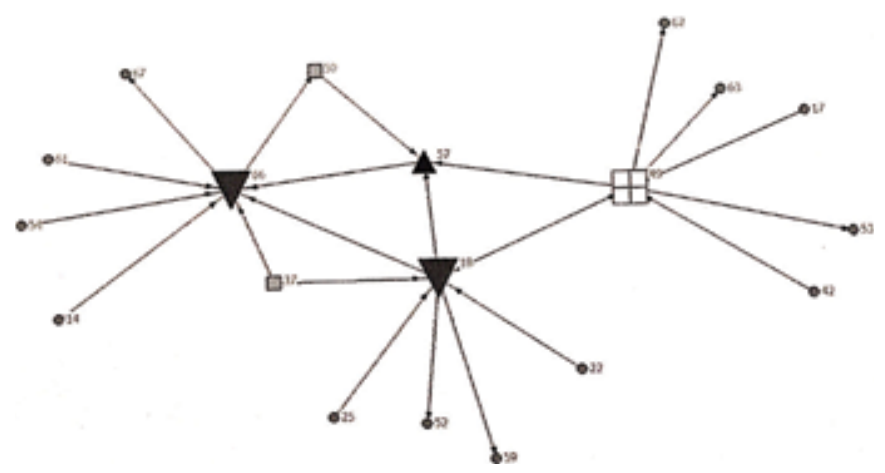

(b)

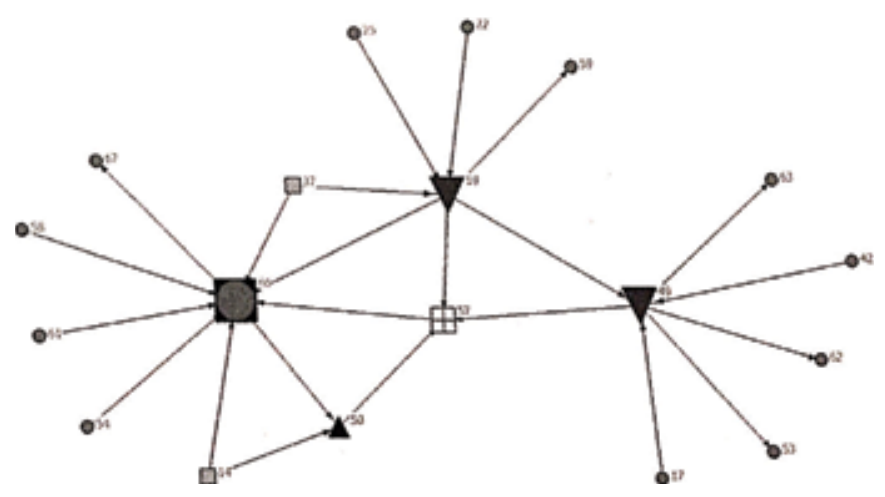

Source: Authors' own elaboration using UCINET VI software.

Note: the node sizes of this figure are proportional to the number of intersectoral connections. The shapes and colours of the nodes were randomly assigned using the UCINET VI software. Sectoral numbers denote productive sectors as shown in Table Al in the appendix.

\section{Concluding remarks}

This article has applied the method developed by Dietzenbacher et al. (2005) to detect the structural interdependencies of the cultural sector and its transformation in Brazil throughout the 2011-2015 period. This method allows us to visualize the productive chains. We constructed the I-O matrices for the years 2011 and 2015. Employing this method, 
we can select the activities with a higher number of linkages within the cultural sector.

The results indicate that the cultural sector purchases inputs from a larger number of activities when compared with the number of sectors that it sells to. In other words, its backward dependency is related to more sectors than its forward dependency. In this way, the cultural sector might be located closer to the end of the productive chain. The number of sectors that it backwardly relies on slightly increased over the period 2011-2015. The opposite happened with its buyers. In this case, cultural activity sold directly to fewer sectors in 2015. The sector is considered a net user. The second distance, representing the indirect effect, shows that this activity exhibited a smaller number of sectors from which it purchased indirectly (two-step dependency) and a larger number of sectors to which it sold its products.

Furthermore, we found that the density of the disaggregated graph (containing the sectors that form the cultural activity) improved in 2015. The total number of linkages increased modestly during the period. Overall, sectors presented intensification in their roles.

This improved "basic" structure and its strong linkages thus indicate the positive contribution of this sector (and its components) to boosting total output. Sectors with high numbers of strong connections must be stimulated, arguably helping to reignite growth. The government's focus on this activity would help to promote a sustainable economic recovery.

\section{References}

AROCHE-REYES, F. Trees of the essential economic structures: a qualitative input-output method. Journal of Regional Science, v. 26, n. 2, p. 333-353, 2006.

BAKHSHI, H.; FREEMAN, A.; HIGGS, P. A dynamic mapping of the UK's creative industries. London: Nesta, 2013. Available at: https:/www.nesta.org.uk/sites/default/files/a dynamic_mapping_of_the_creative_indusindus.pdf. Access in October 2018.

CHENERY, H. B.; WATANABE, T. International comparisons of the structure of production. Econometrica, v. 26, p. 487-521, 1958.

CUNHA, A. M.; PRATES, M. D.; BICHARA, J. S.; VALIATI, L. Impactos econômicos da economia criativa com ênfase no comércio internacional: Conceitos, métricas e estimativas para o caso do Brasil. In: VALIATI, L.; MOLLER, G. (Eds.). Economia criativa, cultura e políticas públicas. Porto Alegre: UFRGS, 2016. p. 96-125.

CUNHA, A. M.; BRITTO, G. When development meets culture: the contribution of Celso Furtado in the 1970s. Cambridge Journal of Economics, v. 42, n. 1, p. 177-198, 2018. 
DASGUPTA, S.; SINGH, A. Will services be the new engine of Indian economic growth? Development and Change, v. 36, n. 6, p. 1035-1057, 2005.

DCMS. Official statistics, key findings, 2016.

DIETZENBACHER, E. The measurement of interindustry linkages: key sectors in the Netherlands. Economic Modeling, v. 9, p. 419-437, 1992.

DIETZENBACHER, E.; LUNA, R. I.; NIELS BOSMA. Using average propagation lengths to identify production chains in the Andalusian economy. Estudios de Economia Aplicada, v. 23, n. 2, p. 405-422, 2005.

FURTADO, C. Cultura e desenvolvimento em época de crise. Rio de Janeiro: Paz e Terra, 1984.

GOSH, S.; ROY, J. Qualitative input-output analysis of the Indian economic structure. Economic Systems Research, v. 10, n. 3, p. 263-273, 1998.

GUILHOTO, J. J. M.; SESSO, U. A. Estimação da matriz insumo-produto a partir de dados preliminares das contas nacionais. Economia Aplicada, v. 9, p. 1-23, 2005.

HENKIN, H.; PAES, L.; VALIATI, L. Mapeamento do sistema federal de incentivo e fomento à cultura. In: VALIATI, L.; MOLLER, G. (Eds.). Economia criativa, cultura e políticas públicas. Porto Alegre: UFRGS, 2016. p. 252-266.

HEWINGS, G. J. D.; FONSECA, M.; GUILHOTO, J.; SONIS, M. Key sectors and structural change in the Brazilian economy: a comparison of alternative approaches and their policy implications. Journal of Policy Modeling, v. 11, n. 1, p. 67-90, 1989.

HIRSCHMAN, A.D. The strategy of economic development. New Haven (CT): Yale University Press, 1958.

KALDOR, N. Causes of the slow rate of economic growth in the United Kingdom: an inaugural lecture. Cambridge, England: Cambridge University Press, 1966.

KORTE, B.; OBERHOFER, W. Triangularizing input-output matrices and the structure of production. European Economic Review, v. 2, n. 4, p. 493-522, 1971.

LEONTIEF, W. Input-output economics. New York, NY: Oxford University Press, 1986.

MESSA, A. Mudanças estruturais na economia brasileira ao longo da década de 2000. Revista de Economia Contemporânea, v. 17, n. 3, p. 452-467, 2013.

MILLER, R. E.; BLAIR, P. D. Input-output analysis: foundations and extensions. Englewood Cliffs, NJ: Prentice-Hall, 1985.

MORRONE, H. Impactos econômicos do audiovisual na economia brasileira. In: VALIATI, L. et al. (Org.). Consumo de audiovisual no Brasil. Porto Alegre: Editora da UFRGS, 2017.

MORRONE, H. Mudança estrutural e coeficientes importantes no Brasil: Uma análise qualitativa de insumo-produto. A Economia em Revista, v. 26, n. 2, p. 17-28, 2018.

NOOY, W.; MRVAR, A.; BATAGELJ, V. Exploratory social network analysis with Pajek. Cambridge, England: Cambridge University Press, 2011.

POTTS, J.; CUNNINGHAM, S. Four models of the creative industries. International Journal of Cultural Policy, v. 14, n. 3, p. 233-247, 2008.

RASMUSSEN, P. N. Studies in inter-sectoral relations. Amsterdam: North-Holland, 1956.

REINERT, S. A. The Italian tradition of political economy: theories and policies of develop- 
ment in the semi-periphery of the Enlightenment. In: JOMO, K.; REINERT, E. (Eds.) The origins of development economics: how schools of thought have addressed development. Input-output analysis, current developments. London: Zed Books, 2005.

REINERT, S. E. German economics as development economics: from the Thirty Year's War to World War II. In: JOMO, K.; REINERT, E. (Eds.) The origins of development economics: How schools of thought have addressed development. Input-output analysis, current developments. London: Zed Books, 2005.

SANGUINET, E. R.; CALVETE, C. S.; WAISMANN, A. P. Economia da cultura e economia criativa no Brasil: uma análise conjuntural do mercado de trabalho (2014-2016). In: VALIATI, L.; MOLLER, G. (Eds.). Economia criativa, cultura e políticas públicas. Porto Alegre: UFRGS, 2016. p. 279-304

SYRQUIN, M. Patterns of structural change. In: CHENERY, H. and SRINIVASAN, T. (Eds.) Handbook of development economics. London: Elsevier, 1988.

SOUZA, N. J. O método dos dígrafos: uma aplicação para a matriz de relações interindustriais do Brasil de 1975. Pesquisa e Planejamento Econômico, v. 19, n. 3, p. 613-642, 1989.

TARANCÓN, M. A.; CALLEJAS, F.; DIETZENBACHER, E.; LAHR, M. A revision of the tolerable limits approach: searching for the important coefficients. Economic Systems Research, v. 20 , n. 1, p. 75-95, 2008.

THROSBY, D. Determining the value of cultural goods: how much (or how little) does contingent valuation tell us? Journal of Cultural Economics, v. 27, n. 3, p. 275-285, 2003.

UNCTAD (United Nations Conference on Trade and Development). Creative industries and development. UNCTAD, 2004. Available at: http://unctad.org/en/docs/tdxibpd13_en.pdf. Access in November 2018.

UNCTAD (United Nations Conference on Trade and Development). Creative economy report 2008. UNCTAD, New York. Available at: https://unctad.org/en/docs/ditc20082cer_ en.pdf. Access in September 2018.

UNCTAD (United Nations Conference on Trade and Development). Creative economy report 2010. UNCTAD, New York. Available at: https://unctad.org/en/pages/PublicationArchive. aspx? publicationid $=946$ Access in November 2018.

VALIATI, L.; CAUZZI, C. Indústrias criativas e desenvolvimento. In: VALIATI, L.; MOLLER, G. (Eds.). Economia criativa, cultura e politicas públicas. Porto Alegre: UFRGS, 2016. p. 186-210.

\section{About the authors}

HenriqueMorrone-hmorrone@hotmail.com

Universidade Federal do Rio Grande do Sul, Departamento de Economia, Porto Alegre, Rio Grande do Sul, Brasil. ORCID: https://orcid.org/0000-0001-9579-8489.

LeandroValiati-leandro.valiati@ufrgs.br

Universidade Federal do Rio Grande do Sul, Departamento de Economia, Porto Alegre, Rio Grande do Sul, Brasil. ORCID: https://orcid.org/0000-0002-0715-1018.

\section{About the article}

Submission received on March 10, 2019. Approved for publication on February 02, 2020. 


\section{APPENDIX A}

\section{Table A1 Disaggregated productive sectors of the Brazilian economy}

\section{Productive Sectors}

Agriculture, including support for agriculture and post-harvest (1)

Livestock, including support for livestock (2)

Forest production; fisheries and aquaculture (3)

Extraction of coal and non-metallic minerals (4)

Extraction of oil and gas, including support activities (5)

Extraction of iron ore, including processing and agglomeration (6)

Extraction of non-ferrous metal ores, including (7)

Slaughter and meat products, including dairy products and fishery products (8)

Manufacture and refining of sugar (9)

Other food products (10)

Manufacture of beverages (11)

Manufacture of tobacco products (12)

Manufacture of textiles (13)

Manufacture of wearing apparel and accessories (14)

Manufacture of footwear and leather goods (15)

Manufacture of wood products (16)

Manufacture of pulp, paper and paper products (17)

Printing and reproduction of recordings (18)

Oil refining and coking plants (19)

Manufacture of biofuels (20)

Manufacture of other organic and inorganic chemicals, resins and elastomers (21)

Manufacture of pesticides, disinfectants, paints and various chemicals (22)

Manufacture of cleaning products, cosmetics / perfumes and toilet preparations (23)

Manufacture of pharmaceutical and pharmacokinetic products (24)

Manufacture of rubber and plastic products (25)

Manufacture of non-metallic mineral products (26)

Production of pig iron / ferrous alloys, steel and seamless steel tubes (27)

Metallurgy of non-ferrous metals and metal smelting (28)

Manufacture of metal products, except machinery and equipment (29)

Manufacture of computer, electronic and optical products (30)

Manufacture of electrical machinery and equipment (31)

Manufacture of machinery and mechanical equipment (32)

Manufacture of cars, trucks and buses, except parts (33) 


\section{Productive Sectors}

Manufacture of parts and accessories for motor vehicles (34)

Manufacture of other transport equipment, except motor vehicles (35)

Manufacture of furniture and products of various industries (36)

Maintenance, repair and installation of machinery and equipment (37)

Electricity, natural gas and other utilities (38)

Water, sewage and waste management (39)

Construction (40)

Trade and repair of motor vehicles and motorcycles (41)

Wholesale and retail trade, except motor vehicles (42)

Ground transportation (43)

Maritime transportation (44)

Air transport (45)

Storage, auxiliary transport and mail activities (46)

Accommodation (47)

Feeding (Alimentation) (48)

Print-integrated editing and editing (49)

Television, radio, cinema and sound / image recording / editing activities (50)

Telecommunications (51)

Development of systems and other information services (52)

Financial intermediation, insurance and supplementary pension plans (53)

Real estate activities (54)

Legal, accounting, consulting and corporate headquarters activities (55)

Architectural, engineering, testing / technical analysis and R \& D services (56)

Other professional, scientific and technical activities (57)

Non-Real Estate Rentals and Intellectual Property Asset Management (58)

Other administrative activities and complementary services (59)

Surveillance, security and research activities (60)

Public administration, defence and social security (61)

Public education (62)

Private education (63)

Public health (64)

Private health (65)

Artistic, creative and entertainment activities (66)

Associations and other personal services (67)

Domestic services (68)

Source: Author's own elaboration. 
Figure A1 The first distance (round) linkages of the cultural sector in 2011 (a) and 2015 (b) in Brazil

(a)

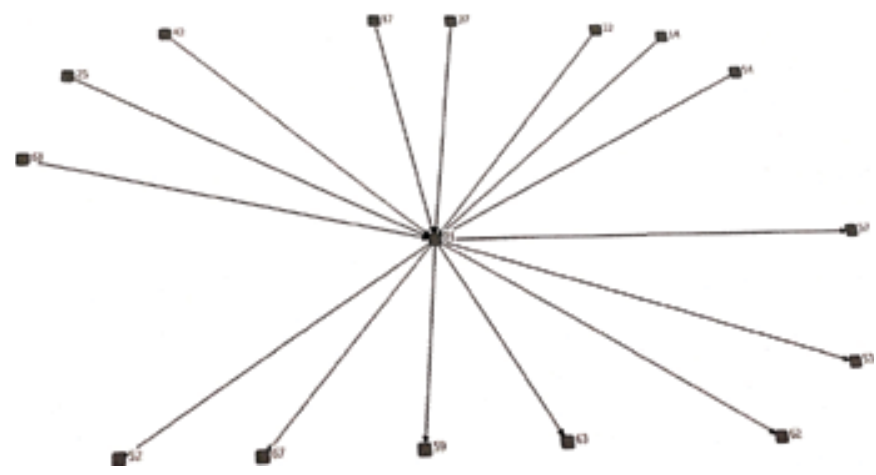

(b)

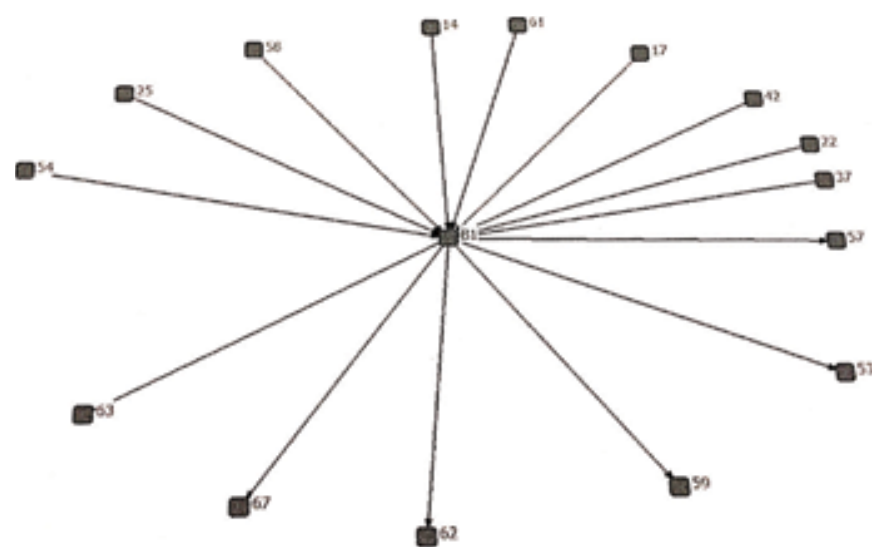

Source: Authors' own elaboration using UCINET VI software.

Note: B1 stands for the cultural sector and its components. 
Figure A2 The second distance (round) linkages of the components of the cultural sector in 2011 (a) and 2015 (b) in Brazil.

(a)

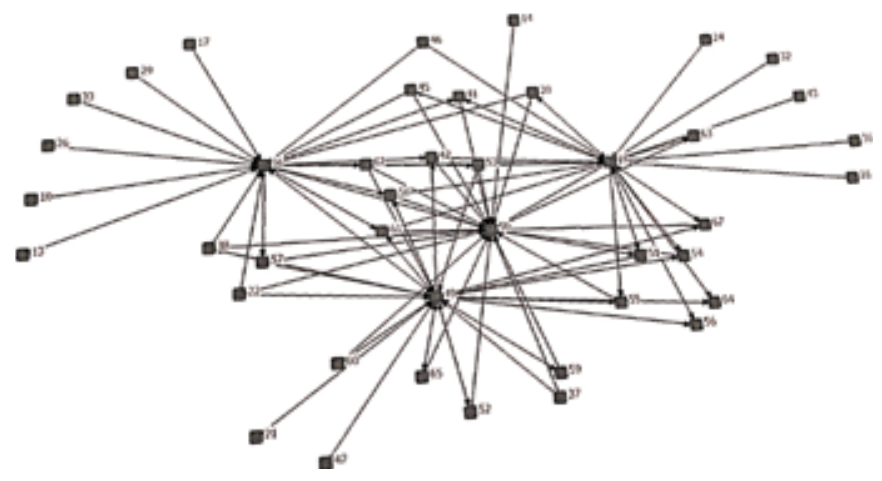

(b)

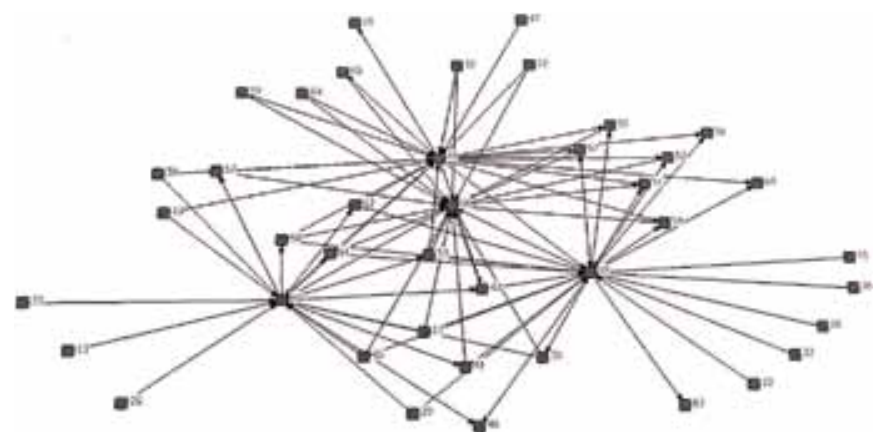

Source: Authors' own elaboration using UCINET VI software. 